\title{
The Metaphors and Its Critical Analysis in COVID-19-Related Cartoons
}

\author{
Yiqing Wang \\ Shanghai Publishing and Printing College/Institute of Modern Media Technology and Art, Shanghai, China \\ Email: wongzoe@126.com
}

How to cite this paper: Wang, Y. Q. (2021). The Metaphors and Its Critical Analysis in COVID-19-Related Cartoons. Open Journal of Modern Linguistics, 11, 539-554. https://doi.org/10.4236/ojml.2021.114041

Received: June 7, 2021

Accepted: July 24, 2021

Published: July 27, 2021

Copyright (c) 2021 by author(s) and Scientific Research Publishing Inc. This work is licensed under the Creative Commons Attribution International License (CC BY 4.0).

http://creativecommons.org/licenses/by/4.0/

\begin{abstract}
By collecting 100 cartoons related to the COVID-19 pandemic from the whole world, this paper uses Yu Yanming's theoretical framework of metaphorical representation from the perspective of multimodal metaphors to classify the metaphorical mappings of these 100 works. This paper also tries to analyze the political stances and attitudes towards the COVID-19 pandemic displayed behind the cartoons. This paper also attempts to explore how the topic is conveyed and communicated via metaphors in COVID-19 cartoons and aims to show how the different metaphor scenario in multimodal discourse becomes a tool for conveying evaluative content.
\end{abstract}

\section{Keywords}

COVID-19 Cartoons, Multimodal Metaphorical Representation, Multimodal Metaphors, Critical Metaphor Analysis

\section{Introduction}

The sudden outbreak of the COVID-19 (named by the World Health Organization as COVID-19) has rapidly turned into a global medical and health security incident, and has rapidly developed into a global pandemic. As of press time, the cumulative number of confirmed cases of the global COVID-19 has exceeded 172 million. From 2020 to 2021, the lifestyles of people around the world have undergone tremendous changes due to the pandemic, and "quarantine" has become an annual buzzword. At the same time, the outbreak of the new pandemic has led to the spewing of news and cartoons related to the COVID-19 pandemic. Compared with language, which has the alias of "Tower of Babel", cartoons, a universal form of communication, can help different human civilizations to understand each other. And also, cartoons would contains multi-modals to construct its' meaning and intentions. These modals would be shown as all kinds of meta- 
phors. According to a lot of news reports, we could see the different expressions of opinions towards the outbreak of COVID-19 pandemic. When different languages could only be understood through translation, cartoons would save several steps to see the cartoonist's attention, so it would be quite interesting to check the opinions and attitude of the countries and areas through cartoons. Most of the COVID-19 pandemic cartoons focused on the actions of governments, the desperate resistance of medical forces, and the impact of the virus on the world, using anthropomorphic and metaphorical methods. Critics described this virus invasion as the deepest influence since the 21st century. "Cartoon is a visual modal discourse that combines the two symbols of image and language. It contains a large number of multimodal metaphors and can insight into the ideology behind it through witty and vivid cartoons" (Ma \& Gao, 2020). With the rapid development of technology, people have gradually adapted to the multi-modal phenomenon composed of text, image, sound, and their interaction. Bounegru and Forceville (2011) define modality as a sign system that uses the senses to construct meaning. He believes that the contact of text, image, sound, smell and taste related to the senses is part of the modality. The linguistic master Lakoff proposed that metaphor has universality, extending metaphor from a single language study to various modalities. Moreover, in the process of constructing the image of the country by the media, language strategies such as metaphor play a very important role (Wang \& Xin, 2019).

\section{Literature Review}

American linguist Lakoff proposed the concept of metaphor in his book Metaphors This Paper Live By. He pointed out that "metaphor is the product of thought and behavior, and it is embodied in language." They believed that from embodied experience (perceptions, behavioral motivations, physical pains and pleasures, coldness and warmth, etc.) would people conceptualize abstract ideas, which leads to metaphors. On this basis, Dutch researcher Forceville proposed the Conceptual Metaphor Theory (CMT), and further proposed that metaphors would not only appear in verbal discourse, but also in images (pictorial) and other multi-modalities discourse expression. Forceville believes that cartoons in journals would be an excellent topic to study multimodal metaphors. In addition, the research scope of multi-modalities also includes advertising, cartoons, gestures, movies, and sculptures. Using the Conceptual Metaphor Theory, we could take political discourse as the object of investigation and reveal the unique role of metaphor in such discourses to further understand political discourse, grasp the function of conceptual metaphor, and broaden the research field of conceptual metaphor (Li \& Zhan, 2013). Zhao (2013) pointed out that the research of multimodal metaphor would normally fall into 4 categories: advertising and cartoons including genre characteristics, distinctive features, the relationship between metonymy and metaphor, and similarities of metaphorical representations. In Bounegru and Forceville (2011)'s studies, they examine the role of visual and verbal 
modalities and argue that metaphors are manifestations of underlying conceptual ones.

After analyzing periodical cartoons, Forceville proposed 4 ways for multimodal metaphors to appear in periodical cartoons: pictorial simile, hybrid metaphor, contextual metaphor and integrated metaphor. Ma Tinghui and Gao Yuan (2020) put forward the target domain implicit metaphor on the basis of this quartile, and pointed out that "Forceville's original framework is aimed at commercial advertising, so it is more suitable for the metaphor of the target domain as a real object." While in the study of Konijn E. A. and Steen G. J. (2013), the data, for instance, show that in the broader process of incongruity perception, visual metaphors are parsed by participants into scenes, whole objects, objects' parts, and background elements. Feng (2011) started his study from the perspective of multimodal metaphor mapping, and constructed a multi-modal metaphor graphic-text representation system, dividing image-text metaphors into 3 categories: cross-modal mapping, intra-modal mapping and multi-modal mapping. When $\mathrm{Yu}$ (2013) analyzed the multi-modal metaphorical representation of news cartoons, and divided them into 6 categories. Lan and Zuo (2016) integrated the theories of Feng and $\mathrm{Yu}$ on the basis of the classification, and proposed 9 subcategories of distribution, which are: under cross-modal mapping: image (source domain)-text (target domain), text (source domain)-image (target domain); intra-modal mapping: image (source domain)-image (target domain)-text (supplement), text (source domain)-text (target domain)-image (supplement); under multimodal mapping: image and text (source domain)-image or text (target domain), image or text (source domain)-image and text (target domain), image and text (source domain)-image and text (target domain); under implicit mapping: implicit source domain-image or text (target domain), image or text (source domain)implicit target domain.

\section{Research Questions and Research Methods}

This paper intends to answer the following questions:

1) As target domains would show the cartoonist's real intention, what are the most used target domains in the COVID-19 Cartoons? Which topics would the cartoonists focused on relating to the pandemic?

2) This paper adopted the classification approach of representation of conceptual metaphors based on Yu Yanming, and according to Yu Yanming's survey, the "image (source domain)-text (target domain)" would account for the vast majority of the proportion as shown in representation of conceptual metaphors. Would this paper have the same conclusion? If not, why?

3) Through the establishment and analysis of conceptual metaphorical mapping, what are the thoughts and worldview behind the cartoons? Are there any differences in the attitudes of cartoonists from different countries towards the pandemic?

4) What metaphorical scenes are used in the COVID-19 cartoons? Did Chi- 
nese and non-Chinese cartoonists break through language boundaries and use the same metaphorical scene?

\subsection{Research Object}

The research objects are Cartoons collected after the outbreak of the pandemic, mainly distinguishing in two categories: the Chinese cartoons and non-Chinese cartoons. The reason to make a difference is that we want to see as a country which maintains a good social order under the attack of virus, how Chinese people regard this pandemic. And for the rest countries who also have a hard fight with virus, what would their reflections. Chinese cartoons are mainly from the official site of China Daily, non-Chinese cartoons are mainly collected from Twitter. All the cartoons were published from February to May, 2020, which would be the outbreak phrase of Covid-19. There are 100 cartoons, of which 50 are drawn by Chinese cartoonists and 50 are drawn by non-Chinese cartoonists. The cartoons from Twitter are drawn by cartoonists from the United States, France, Germany, New Zealand, Jordan, the Netherlands, Austria, Canada, Latvia, Greece, Latvia, Bulgaria, and Romania etc.

\subsection{Research Method}

Using a combination of qualitative and quantitative methods, this paper sorted 100 Cartoons according to the cartoonists' nationalities and multi-modal mapping relationships. The number and proportion of each type of cartoons, the metaphorical representation types and influencing factors of cartoons would be recorded; then, a qualitative analysis method is used to analyze each cartoon to clarify the construction methods and types of each metaphor. Finally, this paper analyzes the ideology behind it and its attitudes and views on the COVID-19 pandemic.

Forceville's criteria for determining whether there is a metaphor are: 1) in a given context, two phenomena belonging to different categories establish a certain relationship; 2) these two different categories of phenomena are often classified as target domain and source domain, and the reverse is also applicable; the three source domain species can be projected to the target domain when they have at least one characteristic or semantic meaning. This kind of projection structure is often a paper-arranged implicit meaning structure.

\section{Research Results and Discussion}

\subsection{The Subject of Target Domain}

After analyzing the target domains of all cartoons, this paper classified these 100 works into the above categories, seen by Table 1 . It should be noted that some cartoon works have multiple target domains, so the number in the final statistics is not consistent with the length of the cartoon works. It can be seen that the works of the Chinese cartoonists mainly focused on the medical staff that played an important role during the fight against the pandemic. There are 18 works 
Table 1. The subject of target domain in cartoons.

\begin{tabular}{|c|c|c|c|c|}
\hline Target domain & Chinese Cartoons & Percentage & $\begin{array}{l}\text { Non-Chinese } \\
\text { Cartoons }\end{array}$ & Percentage \\
\hline Home Isolation & 7 & $12.96 \%$ & 11 & $20.37 \%$ \\
\hline Medical staff & 18 & $33.33 \%$ & 3 & $5.56 \%$ \\
\hline $\begin{array}{c}\text { Donald Trump } \\
\text { Policies }\end{array}$ & 5 & $9.26 \%$ & 14 & $25.93 \%$ \\
\hline Back to work & 0 & $0.00 \%$ & 1 & $1.85 \%$ \\
\hline $\begin{array}{l}\text { Economy } \\
\text { suspension }\end{array}$ & 6 & $11.11 \%$ & 3 & $5.56 \%$ \\
\hline $\begin{array}{c}\text { Global } \\
\text { suspension }\end{array}$ & 4 & $7.41 \%$ & 14 & $25.93 \%$ \\
\hline Blaming China & 6 & $11.11 \%$ & 3 & $5.56 \%$ \\
\hline Political lies & 3 & $5.56 \%$ & 4 & $7.41 \%$ \\
\hline others & $\begin{array}{l}2 \text { images of unity, } 1 \\
\text { image of } 5 \mathrm{G} \\
\text { technology, } 1 \text { image } \\
\text { of response to the } \\
\text { pandemic caused by } \\
\text { differences between } \\
\text { rich and poor } \\
\text { in the west }\end{array}$ & $9.26 \%$ & Impact of NBA & $1.85 \%$ \\
\hline $\begin{array}{l}\text { Total number } \\
\text { of metaphors }\end{array}$ & 54 & & 54 & \\
\hline $\begin{array}{l}\text { Total number } \\
\text { of cartoons }\end{array}$ & 50 & & 50 & \\
\hline
\end{tabular}

drawn by the medical staff as the target domains, accounting for $33.33 \%$ of the total. It shows that in the process of China's fight against the pandemic, the people have been greatly shocked and grateful for the dedication and fortress role of medical staff, which is also the main focus of the media. After analyzing the works of foreign cartoonists, this paper found that there are only 3 cartoons related to foreign medical staff, accounting for $5.56 \%$ of the total. It can also be seen that the situation is the same as reported by the media, because the pandemic situation has not received timely attention. The personnel have not received enough attention, so the death rate of foreign medical staff from infection is much higher than that of Chinese ones. In addition, the top 3 most concerned non-Chinese cartoonists on the pandemic strikes are: 1) Trump's response to the pandemic, $25.93 \%$; 2) the earth hit by the pandemic, $25.93 \%, 3$ ) and social distance isolation, $20.37 \%$. After the outbreak, the Trump administration first ignored the severity of the pandemic, and after the pandemic spread they began to blame China and Obama's medical insurance policy, which caused the pandemic to be the pandemic. The second place is the impact of the pandemic on the planet, $25.93 \%$. It can also be seen that due to the slow response of government policies, the people from all around the world feel shocked about its unbelievable quick spread. Most people did not think of the virus would cause such a huge in- 
fluence on the international world. Ranked third is social distance isolation, 20.37\%. The western countries, especially the United States, have been talking about "freedom", but in the face of life and death, the phrase "social-distancing" has become the opposite of "freedom", as "social-distancing" is just a modest way of saying "quarantine". The number of social distancing Cartoons is also at the forefront. This is in contrast to the Chinese people who quickly quarantined themselves at home during the pandemic. On the issue of quarantine, Chinese cartoonists drew 7 pictures, making it $12.96 \%$ of the whole work. Most of the Chinese cartoons focused on the impact of the pandemic on individuals, that is, social-distancing, working from home, online coursing, etc. In the cartoons which show some national leaders blaming someone else, Chinese and western cartoonists have used the pens in their hands to fight back.

Take Figure 1 of a cartoonist's work as an example. Trump's blaming "game" is portrayed as a game turntable. Trump's report on the pandemic of the COVID-19 virus is not scientifically organized and written, but instead is randomly spun on the game turntable. The option of "blaming China", in which China is portrayed as a panda with fangs, is the use of cultural metonymy, "first play the identity referencing function of these source domains, and then rely on the matter attached to it and its deconstructive relationship between its components generates synergistic interaction between metonymy and metaphor" (Zhao, 2013). In Figure 2, of which is the Chinese cartoonist Luowill's work, the target domain uses both text and pictures. The text part expresses the metaphorical format of $\mathrm{A}$ is B in English and Chinese, while the picture uses accusing gestures to portray the viral tentacles. In addition, the cartoons on the theme of "back to work" accounted one in the collected corpus, drawn by a western cartoonist. Although the spread of COVID-19 virus came from China, the prevention and control of the pandemic is obviously the most effective in China, but the other countries still pay much more attention to "back to work" than Chinese people, and it can be concluded that other countries still do not realize the deeply influences of the pandemic.

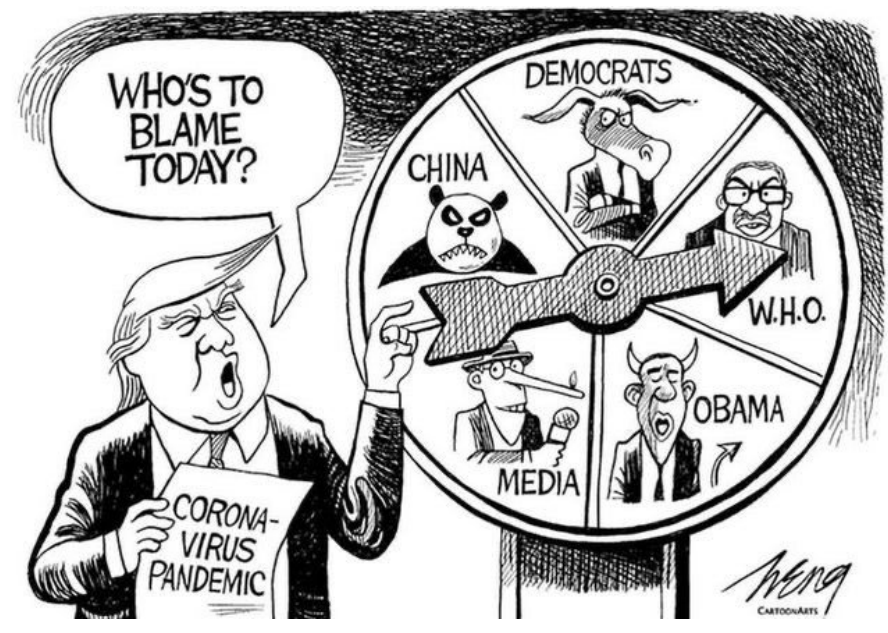

Figure 1. Cartoon by Heng (2020). 


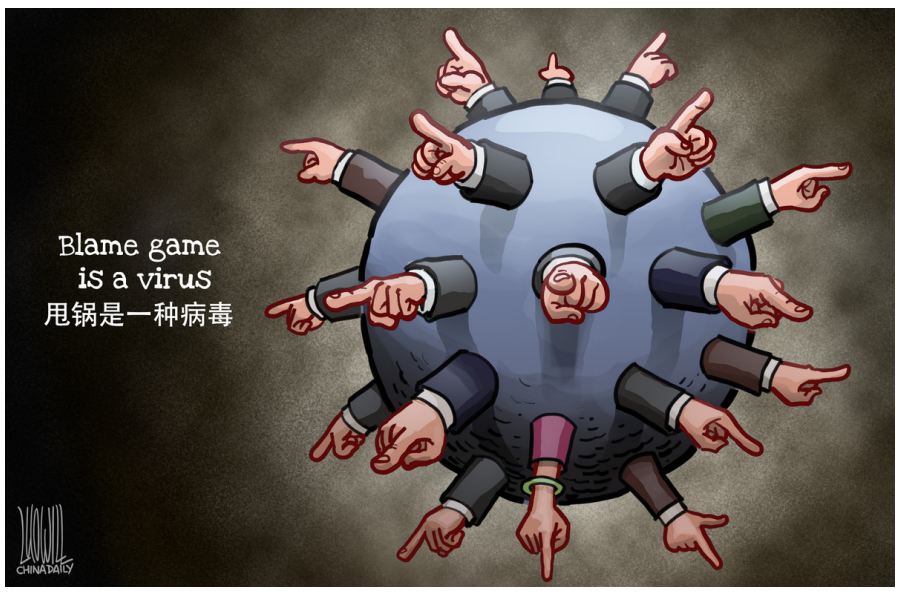

Figure 2. Blame game is a virus by Luowill on China daily (2020).

\subsection{Types of Multimodal Metaphorical Representations}

When classifying the corpus, this paper finds that although the major classification approach is the works of Chinese and non-Chinese cartoonists, cartoonists whose native language is English and cartoonists whose native language is nonEnglish have different emphasis on the choice of multimodal metaphorical representations. In order to clarify the differences, the classification of representation types selected in this paper adopts the theoretical framework of Yu Yanming (2013), namely: 1) Pictorial-verbal metaphors (PVMs), 2) Pictorial-pictorial metaphors (PPMs), 3) Pictorial-semiotic metaphors (PSMs, pictorial-semiotic metaphors), 4) Pictorial metaphors (PøMs, pictorial-ø metaphors), 5) ø VMs, $\emptyset$-verbal metaphors, 6) text $\varnothing$ metaphors (VøMs, verbal-ø metaphors), where $\varnothing$ stands for null. (Seen by Table 2) She believes that the first five types are static mappings, and the sixth is dynamic mapping. Yu Yanming summarized the news cartoons of the Chinesemagazine Half-monthly Talkings and found that the most important mapping method of journalcartoons metaphors is "source domainimage to target domain-text", that is, PVMs. While according to Hu and Liu (2018), Image, text, and text are the main metaphor representation modes, and the two representation forms of image-text and image-text are the most frequently used one. Based on the analysis of the existing COVID-19 cartoon corpus, this paper found that the metaphorical representation of PVMs is as high as PøMs, and after subdividing, cartoonists from non-English speaking countries tend to use PøMs.

This might due to that in the trans-cultural communication, languages might cause a lot of misunderstanding or block the understanding; while pictures would not. So would the cultural differences brought about by language. Chinese cartoonists have adopted the PøMs method as much as possible to convey Chinese political intentions and emotions. And among non-Chinese cartoonists, in addition to cartoonists other than the United States, in other non-English speaking countries, there are also many cartoonists who use the PøMs method, as they try to convey their attitudes through the single mode of pictures. 
Table 2. Types of multimodal metaphorical representations.

\begin{tabular}{ccccccc}
\hline $\begin{array}{c}\text { Representation } \\
\text { Methods }\end{array}$ & $\begin{array}{c}\text { Chinese } \\
\text { cartoonists }\end{array}$ & percentage & $\begin{array}{c}\text { Non-Chinese } \\
\text { cartoonists }\end{array}$ & percentage & $\begin{array}{c}\text { No } \\
\text { Identity }\end{array}$ & percentage \\
\hline PVMs & 17 & $36.17 \%$ & $21(2)$ & $44.68 \%(4.2 \%)$ & 38 & $40.43 \%$ \\
PPMs & 6 & $12.77 \%$ & 2 & $4.26 \%$ & 8 & $8.51 \%$ \\
PSMs & 1 & $2.13 \%$ & 1 & $2.13 \%$ & 2 & $2.13 \%$ \\
PøMs & 23 & $48.100 \%$ & $15(12)$ & $31.91 \%(25.53 \%)$ & 38 & $40.43 \%$ \\
$ø \mathrm{VMs}$ & 0 & $0.00 \%$ & 0 & $0.00 \%$ & 0 & $0.00 \%$ \\
$\mathrm{~V} ø \mathrm{Ms}$ & 5 & $10.64 \%$ & 3 & $6.38 \%$ & 8 & $8.51 \%$ \\
\hline
\end{tabular}

\subsection{Structural Metaphor and Critical Metaphor Analysis}

Although the representation types of multimodal metaphors in Chinese and these western cartoons are different, Chinese and western cartoonists use the same modality in the metaphor structure. All collected Chinese and western cartoons will be analyzed, mainly analyzing the images or multi-modal display of each cartoon. According to the source domain scene of each cartoon, it is classified into the following categories: 1) war metaphor; 2) virus is death;3) journey metaphor; 4) others. And the target domain of all cartoons is undoubtedly the COVID-19 virus or a series of situations related to the COVID-19 virus (analyzed in $4.1)$.

\subsubsection{War Metaphor}

Under this entry, this paper has summarized the metaphor of anti-pandemic like war in all cartoons. Interestingly, the Chinese “抗疫(anti-pandemic)" pronounced the same as the Chinese word “抗议(protest)". Source domain wouldbe fighting the pandemic is like a war. For example, in Figure 3, the scene is placed in a city, the source domain is a few hands extending from the road surface represented by images, and the target domain is represented by words, which represent "quarantine", "lockdown", "social distancing", "testing success". The hand and the virus are confronted in the cartoon, and the clenched hands show that besides a kind of determination, the different meanings they have been given make the virus fled in a hurry. It shows that in the process of fighting the pandemic, these powerful weapons are an important reason for the victory of the "war". In Figure 4, the scene of the cartoon is that after the war, the virus is shown as an image of a matador lying on the sofa leisurely, the gun in his hand is still flaming, and on the other side of the war, the image of Wall Street represents the bull with its head being fixed to the wall as a battle lost. The label under the bull's head says "stock market", and the target domain is displayed in two modal forms: pictures and text.

It is easier to see the use of war metaphors in the cartoons published by China Daily in Figure 5 and Figure 6, the image of "virus" was shown as monsters and strong boxers respectively, and their opponents are shown as medical staff and the earth. Some medical staff wore protective clothing, some only wore white 


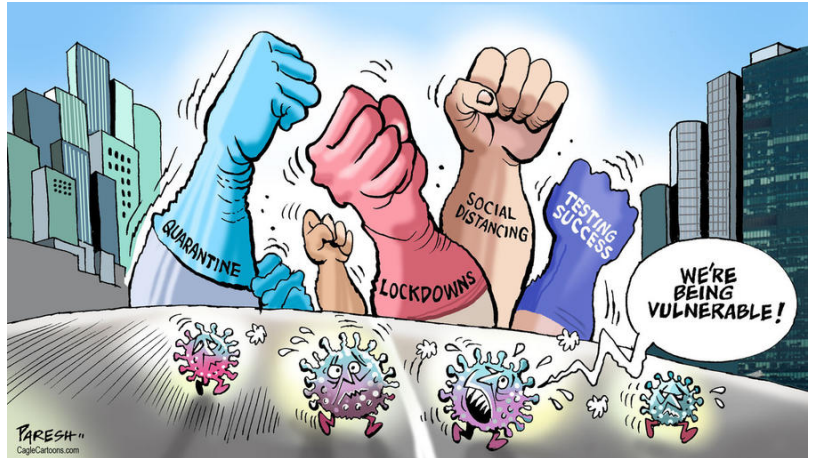

Figure 3. Cartoon by Paresh (2020).

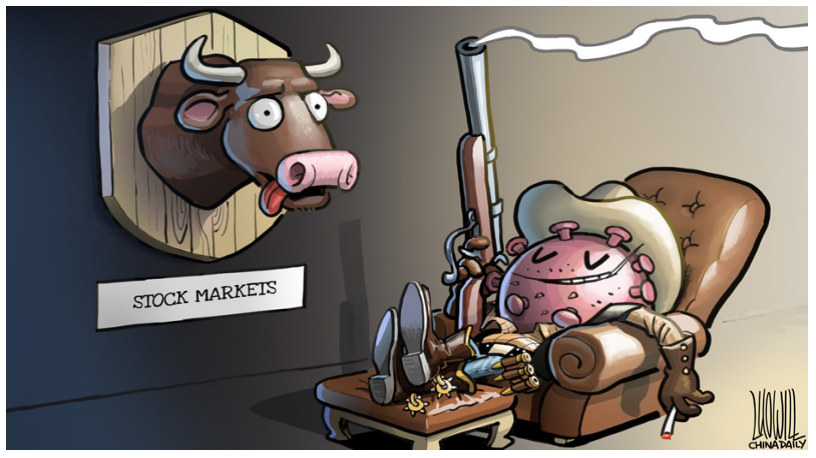

Figure 4. Cartoon by Luowill on China Daily (2020).

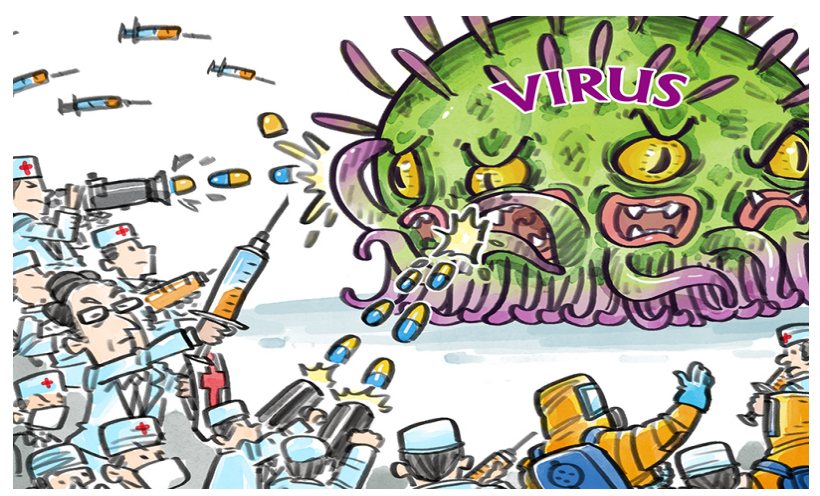

Figure 5. Cartoon on China Daily (2020).

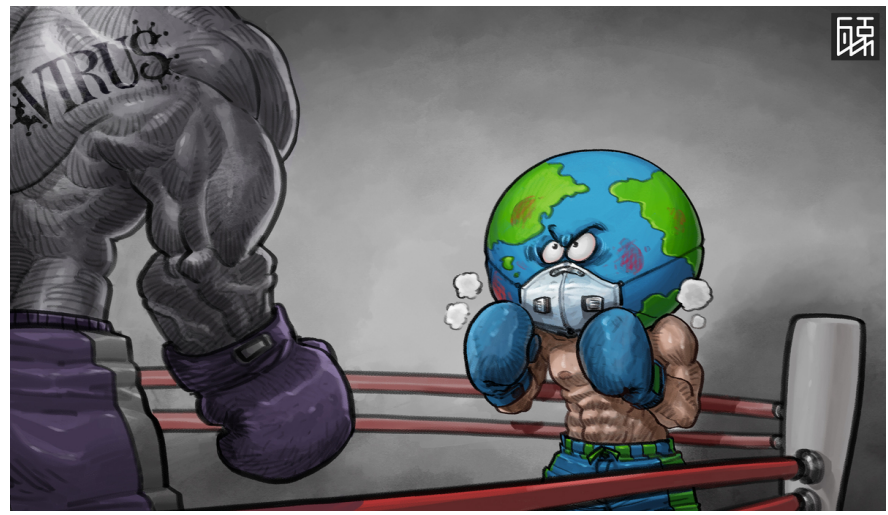

Figure 6. Cartoon on China Daily (2020). 
isolation gowns, and the injection in their hands became a weapon against the virus. In Figure 6, the antagonist of the virus is the anthropomorphic image of the earth, of which is represented as the head of a boxer. Although armed with a mask, the look of the earth is still gasping and exhausted.

\subsubsection{Journey Metaphor}

"Travel along the road to the destination" is a manifestation of journey metaphor (Lakoff \& Johnson, 1980). The journey metaphor proves to be a powerful tool used in political multimodal discourse for a better understanding of the complex relationships between image and text, thought and socio-political context (Silaški \& Đurović, 2019). This paper has found that many foreign cartoons have used the metaphorical expression of journey to show the gradual spread of the virus. In Figure 7, the beginning of the journey is the virus opening its mouth, and the end is the virus swallowing the entire earth, the traveler is the virus itself, and the journey is the process of the virus swallowing the entire earth as shown in the cartoons. In Figure 8, the earth is a traveler and the world economy is a vehicle for travel. During the journey, it is interfered by a virus. Although the windshield has been clearing the virus, the virus gradually invades the engine of the car, hindering the travel of the earth. The car, symbolizing the world economy, had nothing to do but stop, as its engine had been destroyed by the virus itself.

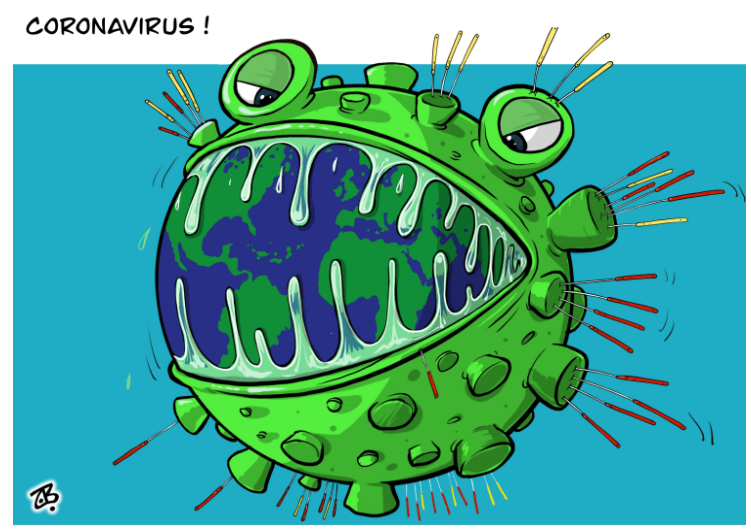

Figure 7. Coronavirus by ZB (2020).

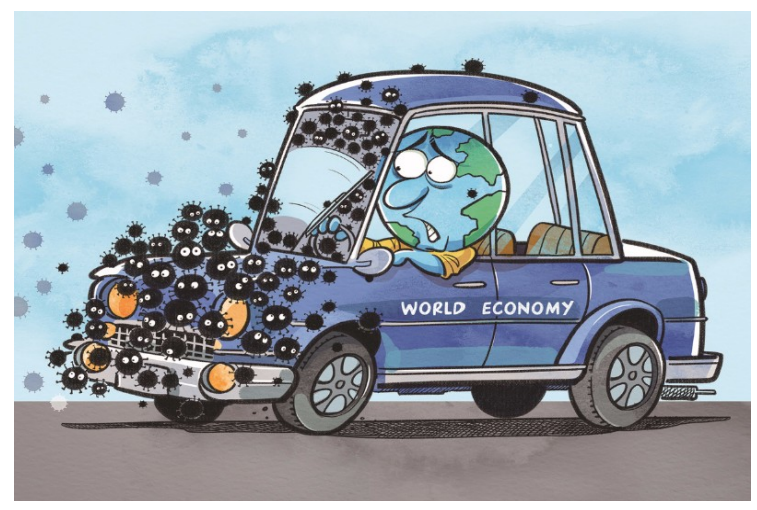

Figure 8. World economy on China Daily (2020). 
Figure 9 and Figure 10 are two cartoons drawn by Chinese and American cartoonists respectively. Both cartoonists used journey metaphors to show the impact of the virus. In Figure 9, the traveler has become the virus itself, and its destination is hidden, but based on common sense, this paper can judge that the virus is spreading and invading the world, which would be his destination. And the bearer carrying the virus walking would be shown respectively as long noses reporters with microphones in their hands, politicians who talked and boasted and politicians who put masks on their eyes making them blind. It is just those bearers who are taking proud and unparalleled steps to help the virus spread much more quickly, so the virus also gave a very satisfied smile in the cartoon. Figure 10 also uses a typical metaphor of a journey. The United States is represented as a large ship on the move. It has encountered the COVID-19 virus "iceberg". While the iceberg was sinking, the US government represented by Trump was still shouting "Stay calm" "life boats and vests are on order", but it can no longer prevent the end of the journey as "sinking".

\subsubsection{Death Metaphor}

Among all the cartoons compiled, the cartoons drawn by foreign cartoonists have multiple metaphors of death, which also shows that the death rate of foreign countries due to the COVID-19 pandemic has been high due to improper control

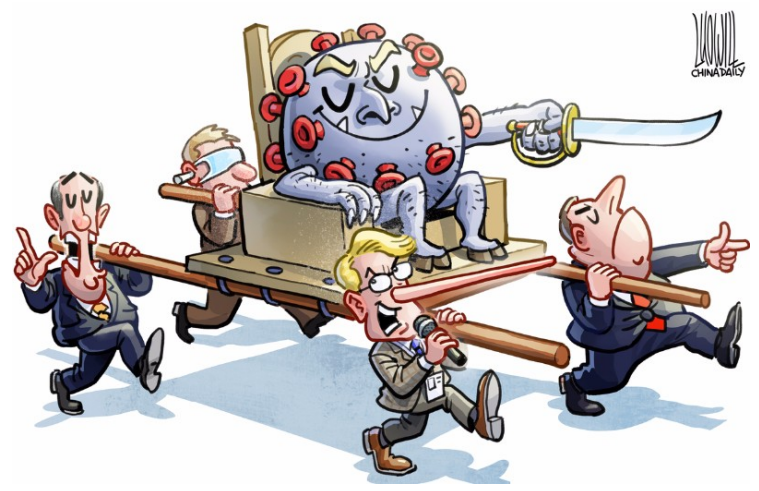

Figure 9. Cartoon by Luowill on China Daily (2020).

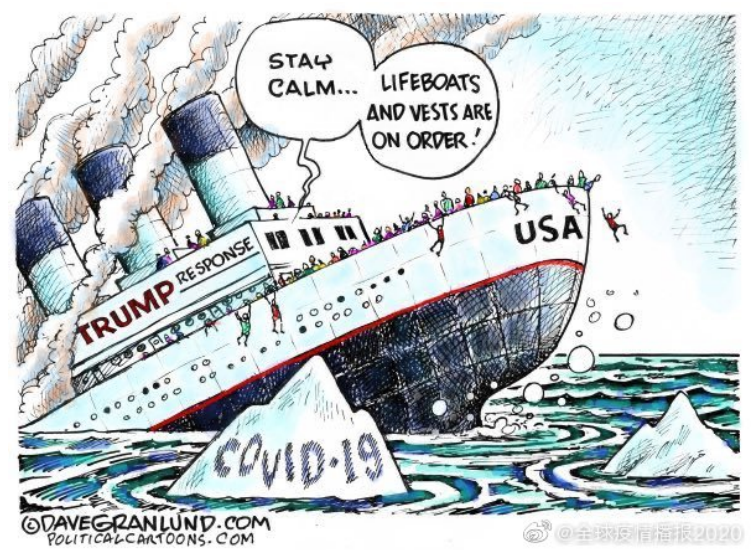

Figure 10. Cartoon on davegaranlund.com. 
of the government.

In Figure 11, the god of death is used as a metonymy of death caused by the COVID-19 virus. He is wearing a black robe and holding a sickle in his hand, which conforms to the description of the god of death in the western world. In Figure 11, the Grim Reaper points to the sea and is portrayed as a beach keeper, while the sign that says "Florida Beach is closed" is covered by a black "Open" sign, and people with black and white skins rush towards the sea. The most densely populated beach does not directly indicate the target area, but the potential outcome of death has been portrayed. Figure 12 directly depicts the scene of the tombstone towering after death. On the tombstone are the politicians and journalists who used to say "the COVID-19 virus is just a hoax" during the pandemic before the pandemic spread, and "this paper controlled the pandemic", "The pandemic will end before April" and "There are a lot of virus reagents." Death is the whole scene, and the corresponding source domain and target domain are hidden.

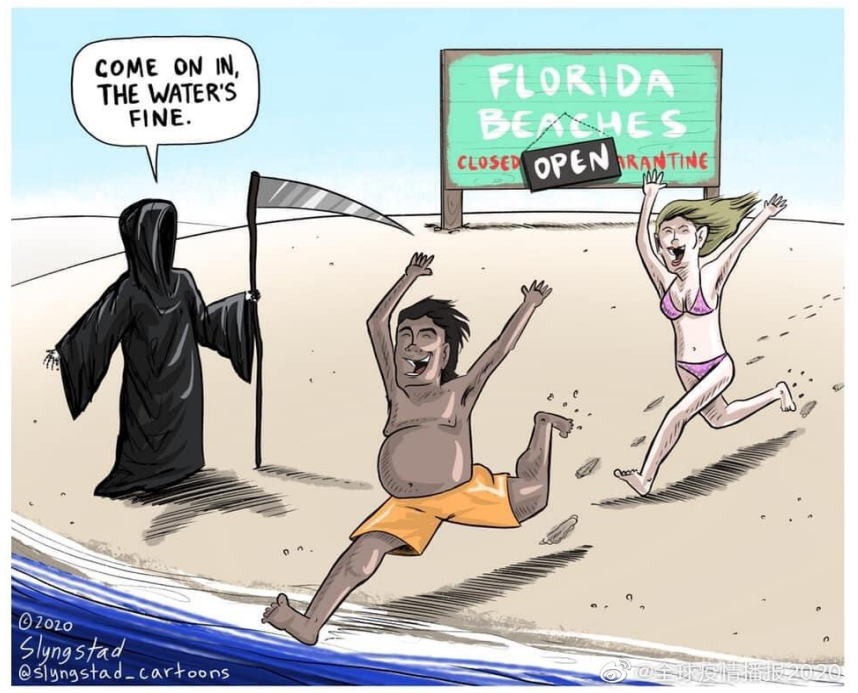

Figure 11. Cartoon by Slyngstad@slyngstad_cartoons (2020).

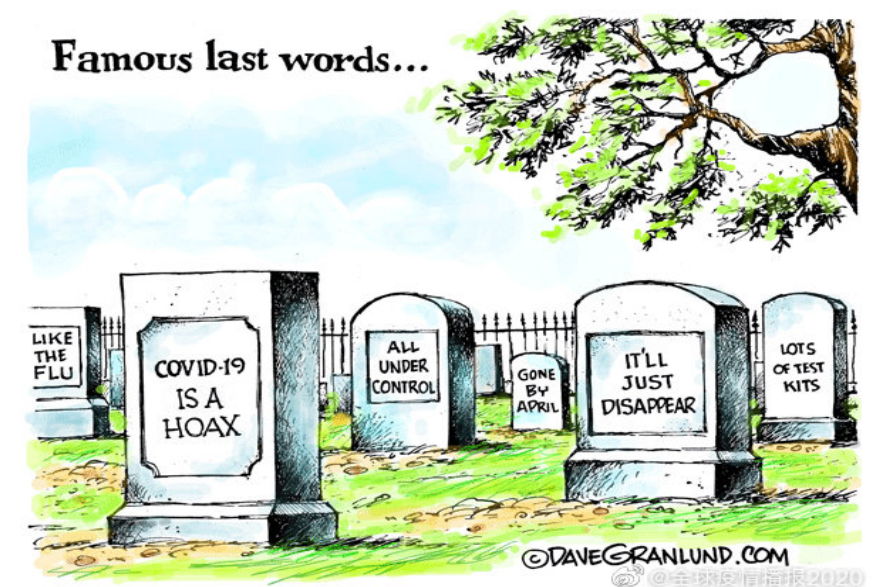

Figure 12. Famous last words@davegranlund.com (2020). 


\subsubsection{Container Metaphor}

The container metaphor mentioned by Lakoff in the book The Metaphors This Paper Live By is also used in the COVID-19cartoons. In Figure 13, the whole earth is compared to a big pot, and the COVID-19 virus has become a popcornlike existence which has exploded entirely, even forcing the lid of the pot to open. It vividly shows the scene of the outbreak of the COVID-19 pandemic. In Figure 14, the U.S. economy has become a lottery box with candies; and the COVID-19 virus ball and many good candies are mixed in. The masks that should be placed on mouth and other important respiratory organs are covered on the eyes. Moreover, there is an extra line of "COVID-19 virus" test written on it. On the one hand, it satirizes the inaccuracy and blindness of the COVID-19 virus test; on the other hand, it also implies that human beings are in the traps of not knowing whether they will draw the virus ball or not, which embodies the characteristics of great randomness that virus carriers are extremely easy to get infected. The use of container metaphor accurately grasps the current spread of the pandemic.

\subsubsection{Other}

There are also some cartoons which have no clear classification method, so they can be discussed separately.

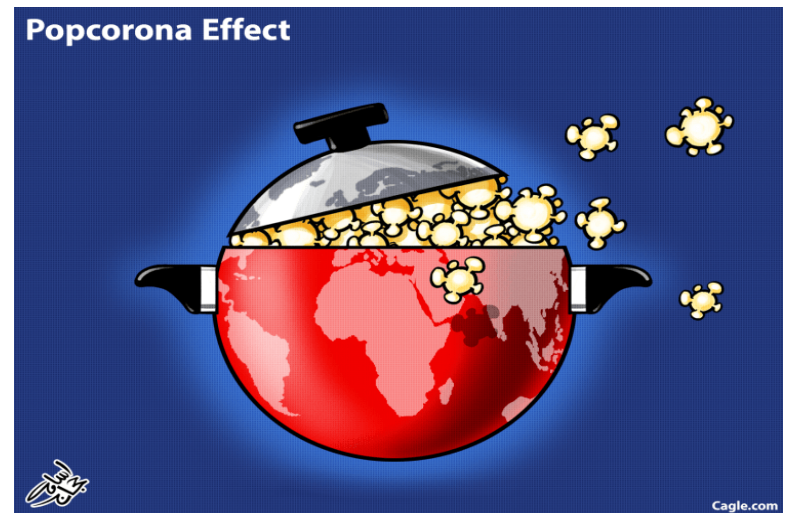

Figure 13. Popcorona effect on Cagle.com (2020).

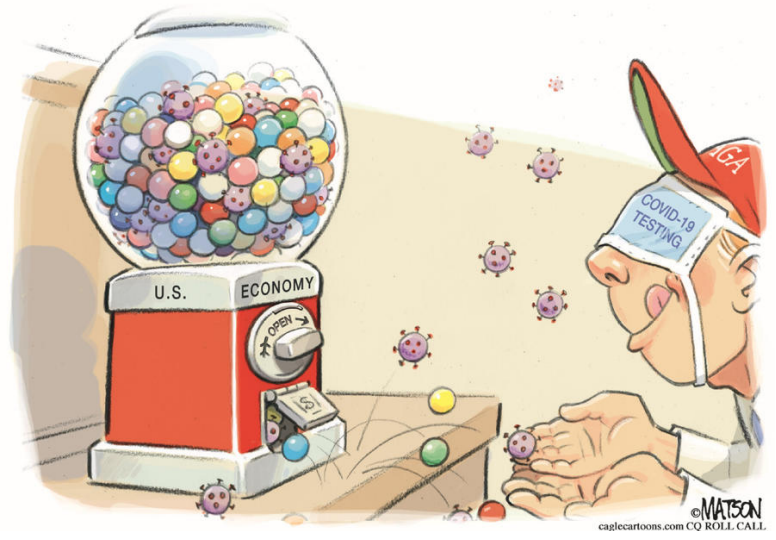

Figure 14. Cartoon on Caglecartoons.com Cq Roll Call (2020). 
Figure 15 is the cover of the American Hollywood Report. The COVID-19 virus is portrayed as the famous "Death Star" in the American science fiction movie "Star Wars". The "Death Star" is a satellite-sized combat space station built by the "Galactic Empire". The early stage of the plan is simply referred to as the "Ultimate Weapon", and the title of the cartoon directly defines the "death star" that grows tentacles as COVID-19 virus, all to map the COVID-19 virus in the real world. The attack on the world and the entire film industry in the movie is consistent with the attack on the entire universe by the "Death Star" in the "Star Wars" system. In Figure 16, Trump is portrayed as a coronavirus, and the text part humorously points out that Trump is "COVID-20", which is updated to

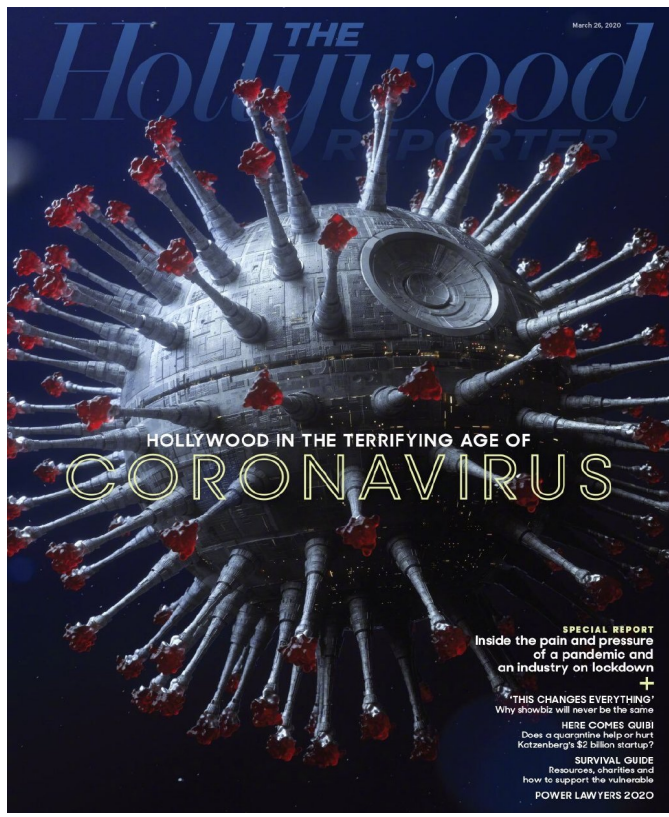

Figure 15. Coronavirus by Hollywood Report (2020).

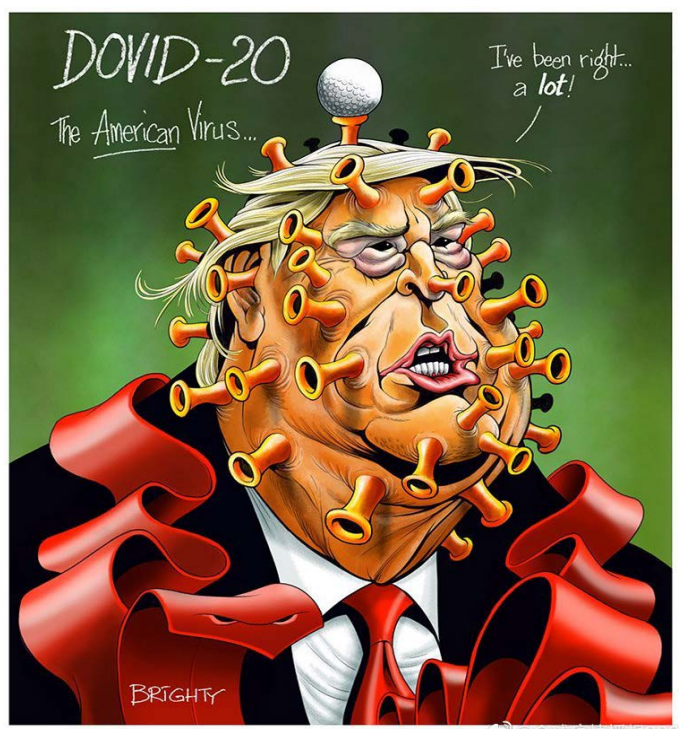

Figure 16. COVIDE-20 by Brighty (2020). 


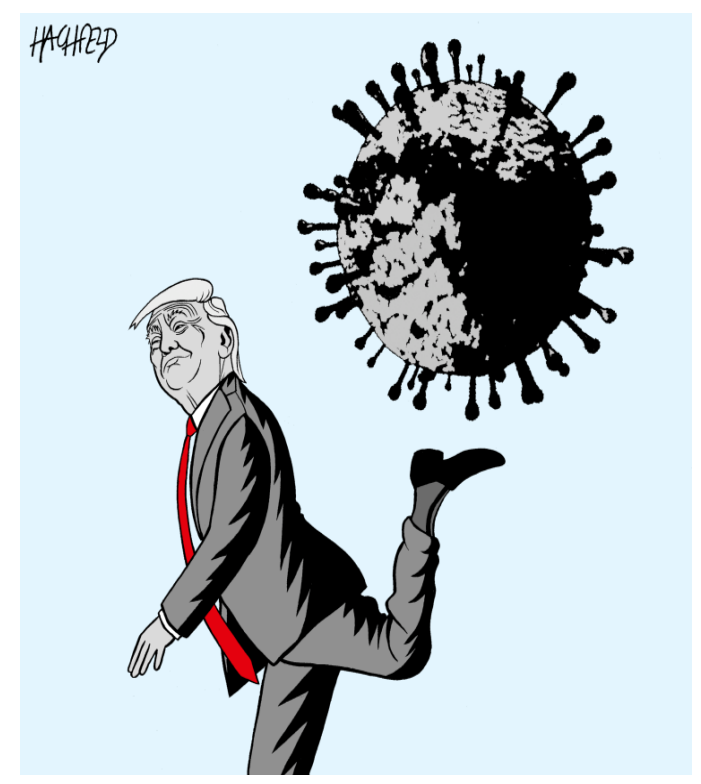

Figure 17. Cartoon by Hagheld (2020).

a new generation of virus according to the medical profession's name for the order of coronavirus. In addition, in the text "The American Virus" line, the line under American was deliberately underlined to express emphasis, and at the same time, it alluded to Trump's national and racial discrimination as calling the COVID-19 virus "China Virus" or "Wuhan Virus". In Figure 17, the COVID-19 virus becomes the earth, being kicked away by Donald Trump, not only insinuating that the entire earth has been covered by the COVID-19 virus, but also showing that Trump has no mercy as he is giving his iconic smile.

\section{Conclusion}

This paper uses Yu Yanming's theoretical framework to divide Chinese and this western COVID-19 cartoon into four categories, and through analysis shows that cartoonists in non-English speaking countries would prefer to use PøMs to map multi-modal metaphors. On the other hand, cartoonists in English-speaking countries try to use more to map in the cartoons to express their themes and political views. After that, this paper analyzes the differences in the structural metaphors and target domains of 100 cartoons to find out the attitudes of Chinese and this western cartoonists who want to convey regarding the COVID-19 pandemic, and the attitudes and developments of different countries when facing the pandemic. Finally, this paper uses Lakoff's classification of metaphor scenes to find out what Chinese and foreign cartoonists have in common when using multimodal metaphors to construct the COVID-19 pandemic.

The lack of research in this paper lies in the failure to collect a cartoon corpus covering more countries around the world to analyze the impact of the global pandemic. Therefore, the situation of some countries that are deeply affected by the pandemic and some countries that have been properly controlled has not been fully demonstrated. Affected by the development of the pandemic, this paper has 
not been able to make a diachronic perspective on the impact of the pandemic on the lives and work of people around the world. It is still waiting for more comprehensive analysis and research in other research articles.

\section{Acknowledgements}

The authors wish to thank Yuerong WU and Jianchao WANG. This work was supported in part by a grant from Zhengyou WANG.

\section{Conflicts of Interest}

The author declares no conflicts of interest regarding the publication of this paper.

\section{References}

Bounegru, L., \& Forceville, C. (2011). Metaphor in Editorial Cartoons Representing the Global Financial Crisis. Visual Communication, 10, 209-229. https://doi.org/10.1177/1470357211398446

Feng, D. Z. (2011). The Construction and Classification of Multimodal Metaphors-From the System Functional Perspective. Foreign Language Research, No. 1, 27-28.

Hu, F., \& Liu, S. M. (2018). Research on Multi-Modal Metaphor Representation Types in Environmental Public Service Advertisements: Taking Water Resources Protection Public Service Advertisements as an Example. Shandong Foreign Language Education, No. 1, 34-45.

Konijn, E. A., \& Steen, G. J. (2013). Processing Visual Metaphor: A Study in Thinking out Loud. Metaphor and the Social World, 3, 1-34. https://doi.org/10.1075/msw.3.1.01sor

Lakoff, G., \& Johnson, M. (1980). Metaphors We Live by. Chicago University Press.

Lan, C., \& Zuo, D. Y. (2016). Images in "Food Safety" News Cartoons-Text Metaphors. Linguistics Research, No. 1, 161-169.

Li, Y., \& Zhan, Q. W. (2013). In Analysis of Conceptual Metaphors in Chinese Political Discourse-Taking the New Year's Day Editorial of People's Daily as an Example. Jianghuai Tribune, No. 5, 85-89.

Ma, T. H., \& Gao, Y. (2020). Multimodal Metaphors Construction and Critical Analysis of American Political Cartoons: The Case of the U.S.-China Trade Conflict. Foreign Language Research, No. 1, 25-32.

Silaški, N., \& Đurović, T. (2019). The Journey Metaphor in Brexit-Related Political Cartoons. Discourse, Context \& Media, 31, Article ID: 100318. https://doi.org/10.1016/j.dcm.2019.100318

Wang, H., \& Xin, B. (2019). On the Construction of China's Image by US Media Based on a Critical Metaphor Analysis of New Coverage on "U.S. Withdrawal from TPP". Foreign Language Education, No. 3, 32-38.

Yu, Y. M. (2013). Study on News Cartoons Multimodal Metaphorical Representation: Classifications, Underlying Mechanism and Genre Features in Terms of Mode Arrangement. Foreign Language Research, No. 1, 2-8.

Zhao, X. F. (2013). The Conceptual Integration Model of Multimodal Metaphor Construction: A Case Study of a Political Cartoon. Foreign Language Research, No. 5, 1-8. 